\title{
Colonization, Education, and the Formation of Moral Character: Edward Gibbon Wakefield's A Letter from Sydney
}

\author{
Bruce Curtis \\ Carleton University
}

\section{ABSTRACT}

Edward Gibbon Wakefield proposed a scheme of "systematic colonization" that he claimed would guarantee the formation of civilized moral character in settler societies at the same time as it reproduced imperial class relations. The scheme, which was first hatched after Wakefield read Robert Gourlay's A Statistical Account of Upper Canada, inverted the dominant understanding of the relation between school and society. Wakefield claimed that without systematic colonization, universal schooling would be dangerous and demoralizing. Wakefield intervened in contemporary debate about welfare reform and population growth, opposing attempts to enforce celibacy on poor women and arguing that free enjoyment of "animal liberty" made women both moral and beautiful.

RÉSUMÉ

Edward Gibbon Wakefield propose que son programme de " colonisation systématique " garantisse la formation de colons au caractère moral et civilisé. Ce programme, né d'une première lecture de l'oeuvre de Robert Gourlay, A Statistical Account of Upper Canada, contribuerait à reproduire la structure des classes sociales impériales dans les colonies. Son analyse inverse la relation dominante entre école et société entretenue par la plupart de réformateurs de l'éducation. Sans une colonisation systématique, prétend Wakefield, la scolarisation universelle serait cause de danger politique et de démoralisation pour la société. Wakefield intervient dans le débat contemporain entourant les questions d'aide sociale et de croissance de la population. Il s'oppose aux efforts d'imposer le célibat au femmes pauvres et il déclare que l'expression de leur " liberté animale " rend les femmes morales et belles.

It is difficult to find areas in modern scholarship from which the work of Edward Gibbon Wakefield (1796-1862), "a doctrinaire theorist with a talent for intrigue," is entirely absent. ${ }^{1}$ History of education would seem to be an exception, one that this article seeks to remedy. Wakefield was a promoter of British settler colonialism, and he sought to profit from a particular version of it. His colonization schemes involved 
governments ceding colonial lands to private companies that would invest in material infrastructure and promote immigration. Would-be settlers, preferably young, married couples, would work for wages on infrastructure projects, such as road and bridge construction and land clearance, in order to earn the purchase price of lots of land. Young settlers would be habituated to sound moral habits, such as foresight, self-control, and frugality. Planned settlements would both concentrate colonial populations and provide investment opportunities for capitalists. Wakefield claimed this scheme of "systematic colonization" would operate automatically to civilize colonists and to reproduce a version of English class-cultural relations. His plans were conducive to rapid population growth, opposed to contemporary Malthusian proposals to limit population by enforcing celibacy on poor women, and, as I show, supportive of a conception of women's material comfort and (hetero-)sexual liberty.

Wakefield rarely engaged directly with issues of colonial schools, colleges, academies, convents, or training institutions, and thus neglect of his work makes sense for a certain vision of educational historiography. Yet the formation of moral character was at the heart of his analysis, as it was for contemporary educational reformers. Such Scottish educators as David Stow, for instance, saw the school as a means of civilizing the working class street, not primarily by its formal lessons, but because exposure to its physical structure and aesthetic dimensions would create moral character in students. Virtually all of Stow's contemporaries agreed that schooling that did not result in the formation of moral character was inadequate at best and spiritually and politically dangerous at worst. They focussed on such formative infrastructures as school architecture. $^{2}$

But Wakefield inverted the relation between formal institutions of learning and conditions in the world around them. Wakefield's claim was that the formation of civilized moral character was a precondition for, not a result of, the operations of schools and colleges. Without the necessary material conditions for the production of moral character in society, he claimed, formal schooling was useless or dangerous to society. He bolstered this claim with an analysis of the demoralizing material conditions that reigned in what he called "new societies." "Systematic colonization" was his proposed remedy.

Wakefield wrote his accounts of systematic colonization in the context of debate and struggle over rapid population growth and proletarianization in England, over the slave trade, and over the effects of settler colonialism on Indigenous peoples and on settlers themselves. His work both addressed and fed on anxieties in the imperial country over the cultural demoralization and degradation thought to result from settler colonialism. ${ }^{3}$ As John Harrington has stressed, settler colonists were assumed neither in policy nor in practice to be fully formed citizens who carried imperial culture with them. Rather, they were in need of civilization and discipline lest they lapse into barbarism in colonial conditions. ${ }^{4}$ How to ensure such training in civilization was an ongoing preoccupation in English liberal and Radical circles, and Wakefield's relations with the English "philosophical radicals" who debated such questions, in particular with Jeremy Bentham, have been canvassed repeatedly. ${ }^{5}$

Wakefield's scheme was remarkably influential. Traces of systematic colonization 
are woven into studies of the design of British colonial cities, into the post-colonial literature on racial hierarchies, on indentured labour in the British Empire, on the campaign against slavery, on land policy in colonial Ceylon and British Columbia, and repeatedly into historical work on Australia and New Zealand. ${ }^{6}$ In such literature, Wakefield has usually been treated narrowly as a political economist. Indeed, Karl Marx studied his work closely, once describing him as "the most notable political economist" of the 1830s. ${ }^{7}$ Yet in Wakefield's period, political economy was explicitly a doctrine of moral economy, and Wakefield meant to ensure the sound discipline of colonists. ${ }^{8} \mathrm{He}$ insisted that systematic colonization would have beneficial effects for England itself by removing surplus labour, thus creating conditions conducive to learning and moral conduct for the working class, while surplus capital would find opportunities for investment in the colonies. The absence of systematic colonization practices, claimed Wakefield, led to unbridled democracy, social degradation, and demoralization; sound practices had the opposite effects. Systematic colonization was thus explicitly a moral-educational project concerned with forming subjectivities and reproducing imperial class hierarchies.

My contribution to the literature on Wakefield and empire probes such educative dimensions of his analysis and his proposals. I begin by pointing to the importance of Wakefield and his work for Canadian educational historiography. I then discuss his pedigree and inheritances in the field of educational reform, which are important in their own right, before examining the doctrine of systematic colonization as it was initially elaborated in Wakefield's A Letter From Sydney (1829). ${ }^{9}$ This exposition is followed by an examination of Wakefield's critique of the effects of existing colonization practices on character and culture, and by attention to his analysis of what he called "new societies."

Wakefield's apparently quaint accounts of the effects of colonial life on women's character and manners, on their bodies and sexual desirability, are passed over in almost all existing accounts. I treat them seriously. They were located in the developing field of ethology (the study of national character), and they contain a materialism which, if crude, nonetheless made an important anti-Malthusian argument. Civilized subjectivity for colonial women involved what Wakefield called "animal liberty," and he claimed that enjoyment of animal liberty made women both moral and beautiful.

\section{Canada}

Canadian educational historians have our own reasons for attending to Wakefield's influence. It was Robert Gourlay's innovative work of social science, A Statistical Account of Upper Canada (1822), that first stimulated Wakefield's scheme. ${ }^{10}$ Since Canadian lands seemed already to have been appropriated by settler-colonists, Gourlay's work initially convinced Wakefield that Canada was not a target for systematic colonization. Yet the Canada Company and especially the British American Land Company, chartered in 1834, pursued versions of Wakefield's plan. John Galt (1779-1839), who was centrally involved in both companies, promoted a scheme akin to systematic colonization in the British American Land Company, and 
Wakefield may appear as a character in Galt's popular novel Bogle Corbet. Galt repeated many of Wakefield's themes, warning, for instance, of "an obvious tendency in the state of things in Canada to favour a relapse into barbarity" among unregulated settlers and working at the moral regulation of Canada Company colonists. ${ }^{11}$ The privatization of Crown lands in the British American Land Company was one of two main grievances of the Reformers and patriotes in the period leading to the rebellions of 1837-38. Wakefieldian schemes were also promoted by the government lands agent, A. C. Buchanan, in Quebec's Megantic region, and Jeremy Mouat and Adele Perry have pointed to the influence of systematic colonization on the colonial settler project in British Columbia. Wakefield promoted his own plans by discrediting alternative Canadian schemes, especially the experiments at "assisted emigration" organized in the 1820s by the Colonial Office official Robert Wilmot Horton. ${ }^{12}$

Despite repeatedly trumpeting his expertise on colonial matters, Wakefield's first direct experience of any colony was as a member of Lord Durham's 1838-39 Royal Commission on British North America. Both Durham and his chief secretary, Charles Buller, MP, were involved in Wakefield's schemes for Australasian colonization, and Wakefield was meant to be Durham's commissioner of Crown lands. The 1820s scandal involving the kidnapping of the fifteen-year-old heiress Ellen Turner by Wakefield and his brother, Wakefield's soon-annulled marriage to her, and his subsequent three-year sojourn in Newgate Prison, prevented a Canadian commission appointment. ${ }^{13}$ Under cover of Charles Buller, however, Wakefield directed the commission's interviews with witnesses, and he wrote the commission's final report.

Included as appendices to Lord Durham's Report on the Affairs of British North America, the reports of both the Lands Commission and the Municipal Commission inquiries were meant to set the stage for a large-scale Canadian systematic colonization project. Lord Durham's report repeated as policy much of Wakefield's testimony before the 1836 imperial Emigration Commission. In Wakefield's earlier writing, it was the fact that most public land in the Canadas had already been appropriated privately that made the colony seem an unlikely site for his projects, but the Lands Commission proposed that such land might be re-acquired by the Crown through a wild land tax, then vested in an imperial commission, and sold according to Wakefield's scheme to those who would bring it into production. Indeed, within two weeks of the commission's appointment, Lord Durham instructed his lieutenant-governors to cease all sales of Crown lands on the grounds that individuals were acquiring more land than they could cultivate. Wakefield's analysis and proposals echoed through the report of the assistant commissioners of municipal inquiry, which lamented that Canadians were unable to acquire "a disciplined knowledge of their social duties in the school of practical citizenship" in the absence of local municipal institutions. Like J. S. Mill, who saw such institutions as "the great Normal School for training the people," Wakefield promoted limited representative municipal government for Canada and for Australasia. ${ }^{14}$

While in 1838-39 Wakefield shared wholeheartedly in Durham's analysis of the necessity of eliminating the French fact in Canada, his position changed when he became the agent for the North American Colonization Association of Ireland in 
late 1840 or early 1841 . This joint stock company paid an inflated price for Edward Ellice's seigneury of Beauharnois and two adjoining townships to the southwest of Montreal, in the pursuit of a scheme closely resembling those of the Wakefieldian 1836 South Australia Company and the New Zealand Company of 1838. The North American Association made heavy commitments to improvements in infrastructure and thus sought to convince government to construct a projected St. Lawrence canal through Beauharnois, rather than to follow a superior route on the river's north side. Wakefield returned to Canada in the summer of 1841 to arrange matters and in 1842 stood for Beauharnois's parliamentary seat, vacated for him by the association's Canadian banker. A vigorous ethnic chauvinist in 1838, Wakefield now courted his would-be French-Canadian constituents with nationalist propaganda and won his seat. There are suggestions that he used his parliamentary influence and access to association funds to suborn government workers who provided him with inside information to bolster his status as the expert on colonial affairs. The Beauharnois route was chosen for the canal and work was begun even before approvals were in place, cementing the choice. Although the colonization project ultimately failed, Wakefield sat in two sessions of the legislature and supported Governor Metcalfe in 1843 against the Reform faction. He left the colony soon after, perhaps $£ 20,000$ richer, and returned his attention to Australasia. In ill health, he emigrated to New Zealand in 1852, where he died in $1862 .{ }^{15}$

\section{Pedigree}

Although he was an indifferent and rebellious student - he left Westminster after three years, refused to return, and was subsequently expelled from the High School of Edinburgh - Edward Gibbon Wakefield was immersed in networks of social improvement and educational reform. His paternal grandmother, with whom he remained close despite his irregular life, was the Quaker Priscilla Wakefield (17511832), a prolific and successful author of improving works for children and young people and of works popularizing arts and science. ${ }^{16}$ Her influence on her grandson's work is evident in the epistolary style they shared, in their interest in the social formation of character, in a concern with sexuality, maternity, and the moral and economic condition of women in society, and in shared opposition to Malthusian doctrine, at least insofar as it promoted celibacy and urged the delay of marriage. ${ }^{17}$

Priscilla Wakefield's work promoted social and self-improvement through the discourse of natural religion, which reconciled science and faith through the systematic investigation of god's glorious creations on earth. Careful investigation and observation gave wholesome pleasure, while deepening and developing the moral powers. The discourse excluded most mystical elements and dovetailed with contemporary anxieties about the demoralizing effects of imaginative fiction. As she put it in her Excursions in North America (1806), "there is no occasion to have recourse to novels or feigned tales, in order to amuse and interest, whilst the occurrences of real life are often so full of extraordinary accidents, and contain more instruction than the fictions of the imagination." 18 
Wakefield's was a very popular body of work directed at the education of middleclass children, especially in a period before mass schooling and before the widespread production of books intended specifically for schools. She worked in the oddly hybrid genre of "observational fiction," not herself travelling or observing, but rather synthesizing the observations of others into narratives written in epistolary style. Her numerous books in this genre exposed juvenile and young adult readers to history, geography, political economy, accounts of morals and manners (proto-sociology), and adventure narratives. Edward Gibbon Wakefield's later A Letter from Sydney aimed to educate politicians and potential investors, not to improve children, but it too was observational fiction in the epistolary style, claiming to instruct and to improve readers through observations of social conditions. ${ }^{19}$

Edward Gibbon likely first learned about British North America from his grandmother's Excursions in North America, although his later analysis was influenced by Fanny Trollope's Domestic Manners of the Americans (1832). ${ }^{20}$ In the Excursions, Priscilla Wakefield led readers through the eastern and mid-southern American states, into the Canadas, and westward to the Pacific. While she devoted some space to describing Indigenous peoples' history and conditions, her grandson later repeated her observations about the scarcity of labour due to easy access to land, and her patronizing accounts of the quaint and superstitious French Canadians. The peasantry was amiable, wrote P. Wakefield, cheerful and welcoming, fond of dancing and singing. The women were "generally very pretty; and their beauty is improved by the tastefulness of their summer dress." Peasant women were worn out from work at an early age, but they were much better instructed than men, most of whom were illiterate, and so women managed household business strategy. The myth of well-educated, enterprising canadien peasant women was repeated by Durham's education commissioner, Arthur Buller, both as a fact and as a denigration of canadien masculinities. ${ }^{21}$

Striking for today's readers is Priscilla Wakefield's 1798 Reflections on the Present Condition of the Female Sex, a contribution to the heated debate about the social and political condition of women provoked by the French Revolution. ${ }^{22}$ The book did not sell well, and Wakefield made few further forays into directly political writing, but Edward Gibbon was early exposed to feminist thought. As with the main English feminist current, there is no hint in this work of approval for the radical familial and sexual politics that formed a leading strand in French revolutionary feminism, and Wakefield was a sharp critic of Mary Wollstonecraft's work, denouncing her personal bondage to "sensual chains" in the absence of marriage and religious faith. ${ }^{23}$ For Wakefield, the natural order of society contained a hierarchy of four social classes, and there was no suggestion that they should be eliminated or that their members should share a common education. Women rightly existed in conditions of domestic subordination and Wakefield assured her readers that educating women would convince them of the rational necessity of patriarchal government.

The feminist thrust of the work came both from Wakefield's insistence that women were rational beings, opposing patriarchal claims of their inherent subordination to the passions, and from her attempts to carve out sites of economic independence for them. Women of whatever social class might find themselves required to fend for 
themselves at some moment in their lives, and they needed to be prepared to do so. In Wakefield's code, women needed to learn to be "useful" in the stations appointed to them, and she criticized existing institutions and practices, including the frivolity of women's education, which unfitted them for usefulness. Much of her book consisted in inventorying the kinds of work in which women from different social classes might learn to find paid employment, should they be widowed, orphaned, or unmarried, teaching among them. She argued that men had no business controlling occupations that allowed them to interfere with women's bodies, such as hairdressing, dancing instruction, stay-making, and undertaking.

Wakefield drew direct connections among women's material conditions, social practices, and their moral character. Writing immediately after the publication of the first edition of T. R. Malthus's An Essay on Population, ${ }^{24}$ which counselled celibacy and the delay of marriage for all those unable to provide for a family, a doctrine she thought cruel, Wakefield wrote that "celibacy, among the inferior ranks especially, is a political evil of such magnitude, as to require every check that wisdom can suggest... Its consequences are fatal." The poor needed to be encouraged to marry early because early marriages "are the most powerful agents to restrain a licentious intercourse between the sexes, one of the prevailing vices among the poor, as the register of every parish proves." Celibacy necessarily led to "a profligate course of life," and so people in the dominant classes should encourage the poor to marry. Offering them financial help to furnish their households was one means, and the cost would quickly be recovered by a reduction of the numbers of bastard children on the charge of the parish. Again, "the establishment of schools for the education of the infant poor, is an encouragement to matrimony," since mothers would be able to work to support the household, and such schooling was "one of the most certain means of producing a reform in the manners of the lower classes." 25 Her grandson would stylize Priscilla Wakefield's insistence on the joys and moralizing effects of companionate marriage.

In the dominant classes, Wakefield argued that the frivolity of women's education and their extravagant love of finery discouraged many eligible men and unfitted women of this class from breastfeeding their babies. As a result, their nursemaids were led to neglect their own children, the bond between mothers and children was weakened across the social classes, the hearts of nursemaids were hardened, and their husbands rendered profligate. The neglect of this and other maternal duties in the dominant classes demoralized daughters, who learned by example, and, as Wakefield put it, "some of the unhappy deviations from conjugal fidelity," which were on the increase, "might probably have never disgraced our courts of justice, nor thrown a public odium upon the sex, had the wretched delinquents fulfilled the tender duties of the maternal character." ${ }^{26}$ Edward Gibbon Wakefield's systematic colonization proposals repeated a version of this analysis as well.

Priscilla's son Edward (1774-1854), who is rather neglected in current historiography, was an early supporter of the French revolution, but a man more interested in politics and social investigation than in earning a living. With the help of London friends, he eventually set himself up in conveyancing - that is, as a real estate agent - but his children were frequently sent to be raised and supported by their 
grandmother, before his wife, Susan, having borne ten children at eighteen-month intervals, died in 1816. Edward's connections to Utilitarian circles proved useful to Edward Gibbon. Edward was close to Francis Place and knew James Mill quite well. He was active in the reform of prisons, asylums, and workhouses. He was a pioneer in social investigation and in the compilation of official statistics, helping to sort out the contemporary "avalanche of numbers" for the reading public. His massive statistical Account of Ireland (1812), the result of a two-year tour, included perhaps the most detailed description and comparative analysis of Irish educational institutions before the work of the 1820s Irish Education Commissions. He denounced the waste of the schools of Royal Foundation and the proselytizing efforts of the education societies, while promoting the work of Joseph Lancaster. He insisted that the successful civilization and government of Ireland demanded popular education in non-sectarian schools. The work cemented his standing in Radical and Utilitarian intellectual circles. ${ }^{27}$

Edward Wakefield was also a leading member of the Radical West London Lancasterian Society. His 1813 survey of educational conditions in London's Drury Lane district (one of the city's first ever house-to-house social surveys) was included in the evidence collected by the 1816 parliamentary committee on working-class education, where he argued for the establishment of fee-paying monitorial schools to avoid the demoralizing effects of charity schools. ${ }^{28}$ The survey drew a direct connection among occupation, income, housing, and moral character. The heated controversy between supporters of Andrew Bell and Joseph Lancaster for the title of inventor of monitorial schooling, in which the elder Wakefield was involved, had cooled by the time Edward Gibbon came of age, but he rehashed it in an essay included in his 1834 England and America. ${ }^{29}$

In effect, both Priscilla and Edward Wakefield produced works of public education, works that were meant to improve and instruct. Priscilla Wakefield's works were very widely read by middle-class audiences. As $\mathrm{Oz}$ Frankel has pointed out, the reports of royal commissions, among which the commission that investigated the conditions of education in the metropolis was a path-breaking example, attracted a very broad readership as well. The reports combined descriptions of events, material conditions, and morals and manners with moral injunctions and policy recommendations. Their descriptions were, of course, by no means innocent. Edward Gibbon Wakefield was thoroughly immersed in discourses that connected political economic conditions to character formation and to the relations between the sexes. ${ }^{30}$

\section{Systematic Colonization}

The scheme of systematic colonization went through a number of iterations in keeping with Wakefield's attempts to promote and profit from it in changing circumstances. Most scholarly attention has been paid to 1834's England and America and the 1849 rehash, The Art of Colonization, because these were the works to which Karl Marx devoted his critical attention. ${ }^{31}$ But the essence of the scheme was already contained in 1829's A Letter from Sydney, and-despite the fact that Wakefield had himself never 
set foot in Sydney — its simple principles for managing land, labour, and capital eventually shaped English imperial policy directly in Australasia and, to a lesser degree, in a great many other parts of the empire for much of the nineteenth century. ${ }^{32}$ The work attracted the attention of the aging Jeremy Bentham because of the self-regulating, machine-like simplicity of the colonization scheme and, after reading it, Bentham veered away publicly from opposition to colonization. Wakefield liked to claim that he was entirely responsible for a change of heart on Bentham's part, but Bentham had read an article on Australia's Swan River settlement in the Quarterly Review before he communicated with Wakefield, and Wakefield's own Letter drew heavily on the Quarterly Review article as well. Those who were attracted to Wakefield's scheme liked the facts that it promised to make colonial resources carry the costs of colonization and to attract emigrants with capital to invest, rather than paupers. ${ }^{33}$

In an appendix to the Letter from Sydney, systematic colonization was summarized in nine "articles" or propositions, which later versions of the scheme repeated more or less closely. The articles held that in the future, free colonial land grants would cease, and all lands would be sold for a sum of money. The sum was not specified in this first iteration, but it was to be what Wakefield would later call a "sufficient price." This was the price that would prevent people from buying more land than they could actively cultivate, while allowing all qualified prospective cultivators to acquire enough land to support a household. Ultimately, the "sufficient price" turned out to be an illusory figure.

All granted land would be subject to what Wakefield called a "rent tax," to be collected as taxes currently were in England, and this tax would constitute an Emigration Fund to subsidize the passage of qualified emigrants directly. Instead of giving poor emigrants their passage money and subsequently attempting to recover it from them, the direct subsidy would obviate the problems that resulted when emigrants drank their passage money or sold all their possessions on arriving in a colony in order to repay it. Such "inconveniences," Wakefield commented, "are the reasons why Mr. Wilmot Horton's benevolent plan" for assisted emigration "has been received by all parties, with apathy, if not with dislike." ${ }^{34}$ The administrators of the Emigration Fund would be allowed to use it as security for raising loans for colonial improvements. To inform the home government accurately about the local demand for labour, to receive emigrants on their arrival, and help them find work, an "Agent of Emigration" was to be appointed in each settlement. In this way, the supply of and demand for labour would be matched. Young people were to have preference for assistance to emigrate and equal numbers of the sexes were to be sent.

Despite denouncing the holding of uncultivated tracts of land as a barrier to sound colonization in his social analysis, Wakefield nonetheless proposed that land grants might be obtained in a colony of settlement by the deputies of people in England. These deputies would pay the purchase price and the rent tax for land and would promote settlement. The argument presupposed the formation of for-profit private land companies as an outlet for surplus English capital. Any surplus generated by the rent tax would be devoted to public improvements, the execution of land surveys, and other necessary elements of settlement. 
In 1829, Wakefield wrote that his scheme "could not be applied to Canada. Because the vicinity of the United States would induce emigrant labourers to emigrate once more in search of waste land, or extravagant wages; and the purchasers of waste land in Canada, would thereby be cheated of their consideration." He abandoned the position before coming to Canada with Lord Durham. ${ }^{35}$

\section{Maladies and Remedies}

Apart from the preceding pedestrian description of his scheme, the Letter from Sydney was written in a style meant to captivate a readership preoccupied by domestic surplus population, the slave trade, indentured labour, convict settlement, and moral degradation in the colonies. It contained sensationalist, sometimes lurid, and purposefully counterintuitive accounts and arguments to hammer home the threat of unregulated colonization to British civilization. Some material was titillating, and Wakefield played on the political anxieties of his audience, rambling over a large number of subjects before ending with the "Articles" described above. Yet systematic colonization was a remedy for a set of social ills that Wakefield diagnosed, and it is both diagnosis and remedy that interest historical sociologists and educational historians.

The colonial maladies that he diagnosed stemmed from the demoralization caused by mixing convicts and free settlers, from a disproportion between population and territory, and from an imbalance in the numbers of men and women. Together they led to intellectual, moral, cultural, economic, and political decline, and such was the inevitable state of affairs in what Wakefield called "new societies." Systematic colonization was a remedy not only for these ills, but also for the alarming explosion of both wealth and pauperism in the imperial country - the "condition of England question." The removal of surplus labour and surplus capital from England would not only create material comfort in the colonies, but would heighten the demand for production in the imperial state. That in turn would lead to increased wages, material comfort, leisure for learning, and thus, increased civilization in the labouring population, England's “internal colony.”

"New societies" were not defined by the period of their establishment, "for, according to our sense of the word, the Canadians will probably be a newer people fifty years hence than they were fifty years ago, and the United States' Americans are a newer people now, in 1829, than they were in 1779." Simply put, "newness" referred to "an excess of territory in proportion to inhabitants," and for Wakefield, new societies were composed of people whose numbers increased but who made "no progress in the art of living; who, in respect to wealth, knowledge, skill, taste, and whatever belongs to civilization, have degenerated from their ancestors." Unless they used slave labour, they could never be wealthy, and although there might be universal schooling in such societies, it stopped "before the age of puberty" and so was "if not an evil, at least a dangerous thing." Without Wakefield's proposed reforms, schooling could not civilize those in new societies. ${ }^{36}$

People in such societies were transients who could never perfect anything; their "opinions are only violent and false prejudices, the necessary fruit of ignorance." 
Their "character is a compound of vanity, bigotry, obstinacy, and hatred most comprehensive, including whatever does not meet their own pinched notions of right." They took pleasure in "a forced equality," which was against nature, and such equality "rewards the mean rather than the great, and gives more honour to the vile than to the noble." In sum, the people of new societies "become rotten before they are ripe." 37

The dispersal of people over territory caused by easy access to land was a root evil that led to a scarcity of wage workers. The Letter stressed that conditions in Australia prevented the recreation of English class relations. Wakefield's imagined author reported that although he had repeatedly brought skilled craftsmen and agriculturalists to the colony, that he had tried to hire convict labour to cultivate his lands, or to put his capital to work, time and again, all species of workers abandoned him as soon as they had saved enough money to acquire land of their own. Colonial wages were outrageously high and house rents in Sydney were astronomical, but still there was a debilitating shortage of labour for hire. He had no power over workers: "I became the slave of my slaves," he complained. In other colonies, the shortage of labour was remedied by the introduction of slavery and, looking at the miserable condition of his colony, "I began to hanker after, what till then, I had considered the worst of human ills - the institution of slavery." If the colony achieved independence tomorrow, he warned, it would certainly introduce slavery - one can imagine the shudders from the abolitionist readers of the Chronicle — and so "I constantly ask myself, whether it be possible to devise any means by which to establish, in a new country, such a proportion between people and land as would render labour plentiful, and not extravagantly dear." 38

While easy access to land gave the colonists high wages and rude material comfort, the shortage of labour prevented capitalist accumulation and economic improvement. The consequent flattening of the class structure prevented the colony from developing the broad cultural refinements supposedly produced by the aristocracy and the bourgeoisie in the imperial country. The non-convict settlers were "farmers, army and navy surgeons, subalterns on half-pay, and a number of indescribable adventurers, from about the twentieth rank in England." They were all like the "English sluggard of Boulogne," but they were better off in Australia because they had to work or starve, and even a rat-poor English second lieutenant could acquire land and possessions. Yet the necessity of working faced by all meant that colonial "ideas are confined within a circle extremely narrow" and "science, morals, manners, abstract politics, are subjects of little interest, unless they happen to bear upon the wool question." Relative material comfort combined with cultural poverty to produce vulgarity and political despotism. ${ }^{39}$

Similarly, in America, relative wealth did not lead to leisure, reflection, or selfcultivation. Instead, the high price of labour caused by the easy availability of land encouraged sloth. The Letter retailed the story of the American youth of good family who quit school against his father's wishes to head west, and who ended up working three days a week in order to stay continually drunk, when he could have become wealthy by staying in New York and following a regular course of life. In America, 
the correspondent from Sydney met "a people without monuments, without history, without any love of birthplace, without local attachments founded on impressions of the past," and he learned that with "a new people, restlessness is a passion, insatiable whilst any means of indulging it remain; a disease, incurable but by cutting away all its source." The passage about a country without history re-appeared to describe canadiens in Lord Durham's Report, where it continues to be read as deeply insulting by québécois nationalists. ${ }^{40}$

Wakefield's fictive correspondent claimed that the bane of democracy-levelling and the tyranny of the majority - grew when people had a little wealth but less knowledge. Violent political oppositions obtained in new societies because no social class had the leisure to reflect on political matters and governments were despotic because of their control over land and because of the dispersion of settlement. Democratic manners invaded all cultural spheres and "whilst in old countries, modes and manners flow downwards from the higher classes, they must, in new countries, ascend from the lowest class." Matters were especially bad in Australia because of the mixing of convicts with free settlers: "the base language of English thieves is becoming the established language of the colony. Terms of slang and flash are used, as a matter of course, everywhere, from the gaols to the Viceroy's palace, not excepting the Bar and the Bench." ${ }^{41}$

\section{Gender Relations}

Wakefield saw the disproportion of the sexes as a prime source of cultural and moral degradation, in Australia under the convict system, but in new societies more generally. Colonial population must be prolific, and to ensure this, as an early pamphlet from Wakefield's National Colonization Society insisted, there must be "a selection of Emigrants whereby the greatest amount of procreative power would emigrate at the least expense that is in the least number of persons." ${ }^{42}$ Wakefield's remedies for imbalance between the sexes were straightforward, and he insisted that "every new government... possesses the power to civilize its subjects" if only it would do so, ${ }^{43}$ but the Letter wandered through lots of gossipy material to get to them. He included a discussion of the connection of class relations and material comfort to female beauty and sexuality.

Relations between the sexes were an element in the analysis of "national character," systematized somewhat later by people such as J. S. Mill as the field of ethology, part of "the social science." ${ }^{44}$ Parts of this discourse were well-established and were popularized by Montesquieu's early eighteenth-century arguments about the effects of climate on social organization. ${ }^{45}$ More influential for the Wakefields was David Hume's essay "Of National Characters," which examined differences among nations in terms of both "moral" and "physical" causes. Moral causes created habitual manners and they were to be found in "the nature of the government, the revolutions of public affairs, the plenty or penury in which the people live, the situation of the nation with regard to its neighbours" and so on. Physical causes included "those qualities of the air and climate, which are supposed to work insensibly 
on the temper, by altering the tone and habit of the body, and giving a particular complexion." 46 Priscilla Wakefield's Sketches of Human Manners (1811) was in the same discursive field, and contemporary social analysis commonly claimed that the topology of bodies and the nature of desires were shaped by climatic or religious or social conditions. Even the language spoken by a people was held to shape its national facial form. What was specific to Edward Gibbon Wakefield's version was its anti-Malthusian promotion of prolific population increase and the exercise of sexual liberty by women.

An early section of the work promised an exciting account of colonial prostitution - by "currency lasses" — but delivered nothing of the sort. Rather, Wakefield wrote that the women of Sydney were not to be called "women": they styled themselves "Ladies," but colonial conditions caused forms of social intercourse to be hollow and stilted. Adult women spent their time on "all those very, very little things, which occupy the minds of women not strongly tempted to acquire, either delightful knowledge, or the other arts, meaner than knowledge, by which superior men are pleased" (an echo of Priscilla Wakefield's critique of the results of women's English situation). But the "greatest evil of all" in Australia was the disproportion between the sexes, which led to the generalization of prostitution. Even respectable men had recourse to prostitutes in the colony, while all attempts to ban prostitution were bound to fail in the colony as in England. ${ }^{47}$

In the short term, Wakefield urged the despatch of women and children to Australia to resolve the imbalance of the sexes in the colony and to diminish poverty and prostitution in England. More women in Australia would lead to a rapid increase in the colonial population, and he claimed both that the colony could support a large and growing population and that marriage and reproduction made women at once moral and beautiful. His section on "currency lasses" took its title from the remark of some English observer to the effect that English women were "sterling," while colonial women were "currency": that is, the latter were debased versions of the former. This Wakefield contested.

In titillating passages full of remarks about alluring bodily shapes and handsome ankles, Wakefield affirmed that women were indeed most beautiful in the English ruling class, and for good reason. Wealthy men married women for their looks, and "not only does the highest class pick out the beauties of two or three classes, but it also keeps its own beauties." Yet men intending to emigrate need not fear that colonial life would make Australian women ugly. All would agree that the standard of female beauty was set once and for all by the women of Greece, and Sydney was at the same latitude as Paphos. He continued:

The Australian youth are neither chubby, ruddy, and strongly knit like the English, whose otherwise variable climate is almost constantly wet; nor fat, white, thick-skinned, and shapeless, like the Dutch, whose climate is one fog, dripping or frozen; nor indescribable, like the mongrel French, whose climate is neither one thing nor the other; and they are still less like the Americans, whose climate, more variable than that of England, is always in extremes... but 
they Resemble the Castil[1]ians, the sea-coast Italians, and more especially the island Greeks, which last enjoy, like them, perpetual summer upon a soil not alluvial. ${ }^{48}$

How did climate determine female beauty? It did so to the extent that it freed women from want and made them comfortable physically, hence happy and contented, and thus moral. Moreover, he went on:

Happiness includes animal liberty, and misery includes restraint. Whatever the human variety, a face of joy and a form of ease make the perfection of beauty; whilst general deformity is the type of suffering and constraint. As we feel and act continually, so shall we appear. Thus, after all, soil and climate may produce beauty or ugliness by a moral rather than a physical process. ${ }^{49}$

Wakefield's analysis joined conditions of life and labour equally to character formation and to bodily formation using a rather conventional interpretive grid.

What distinguished Wakefield's position in this matter was in his invocation of women's "animal liberty," a code for the free exercise of sexual intercourse (within heterosexual marriage). Here he was arguing against the misery and constraint that were Malthusian preventives of overpopulation. As Priscilla Wakefield had extolled the joys of marital sexual reproduction, so Edward Gibbon Wakefield claimed that a fecund colonial population would resolve the problems both of England's supposed surplus population and colonial cultural backwardness.

Of course, Christian doctrine and the social policy of Christian churches had long urged people to be "fruitful and multiply," and in the contemporary Canadian case, the fecundity of French-Canadians was a source of national pride. Sexual pleasure aiming at reproduction within marriage was encouraged by the Catholic Church. ${ }^{50}$ But Wakefield was writing in an English context in which a reforming bourgeoisie was attempting to restrain working-class sexual conduct in an effort to end pauperism. Attacks on the existing Poor Law, or the so-called "Speenhamland System," reached a crescendo in the late 1820s and early 1830s, resulting in the new Poor Law of $1834 .{ }^{11}$ Under the old system, landed property was taxed to support the poor in their homes in their parish of origin, a provision that increasingly cast the costs of capitalist accumulation onto property in land while limiting labour mobility, and supposedly, encouraging unregulated population growth among the poor and the proletariat. T. R. Malthus's work often targeted men, arguing that it was their contracting of improvident marriages that led to overpopulation and pauperism. ${ }^{52}$

But other writers argued that it was the social and cultural situation of women that was at issue, particularly their indulgence of their "sensuous appetites" under the conditions of the Old Poor Law. Reformers were especially incensed by the ability of women who bore children out of wedlock to name the putative father and to claim financial support from him, or from the parish. Priscilla Wakefield's opposition to enforced celibacy and her promotion of early marriage for the poor in her Reflections was a contribution to this debate. 
Alexis de Tocqueville summarized the reform critique after observing English conditions and consulting opponents of the old Poor Law in the early 1830s. "A people's good morals and manners almost always depend on women and not on men," he wrote. Men would always "attack. The point is thus to make it so that they are resisted." And anything that made the position "of women who fall" easier was eminently immoral — including provisions that permitted unmarried women to identify their children's fathers and to claim maintenance. Indeed, according to Tocqueville, because an unmarried woman with children was eligible for parish support, she "will thus have an infallible means of diminishing the consequences of her shortcomings, even a way to make them profitable. Thus it is in England that a girl of the common people who has bastard children finds it generally easier to marry than a virtuous girl." 53 The so-called "Bastardy Clauses" proposed by the commissioners for the 1834 Poor Law, inspired directly by Malthusian doctrine, attempted to impose the entire burden of child support on unmarried mothers, sending them to workhouses and thus aiming to force them into celibacy. ${ }^{54}$

There was no such discourse of restraint in E. G. Wakefield, and a consideration of his work may nuance current debate around Malthusian bio-politics. ${ }^{55}$ Fecundity and the elimination of pauperism and overpopulation were perfectly compatible; women under sound colonization policy would give free reign to their "animal liberties."

For Wakefield as well, it was law and legislation that formed women's sexual conduct by determining their material condition, but he argued that their material condition and liberty in sexual conduct in turn determined their beauty and character. Governments had the power to make new societies into moral societies by civilizing colonial subjects and by allowing women and men their "animal liberty." For Australia, the short-term solution was the immigration of more women. The real solution, however, was Wakefield's plan for systematic colonization. To this end, "the government might, by restricting the amount of [land] grants, establish and maintain the most desirable proportion between people and territory" and "a wise government would grant just enough land to enable the people to exert their utmost capacity for doubling themselves, but no more [land, that is]." 56

For Wakefield, emigrants to be subsidized in a scheme of systematic colonization should be "young persons only, and especially young couples of both sexes," those without young children. Such a practice would balance the numbers of the sexes. Since the young were most adventurous, they would be most willing to go as couples to a colony, while they would also be better able to adapt to a new climate and to new ways of working. The prospect of raising a family and acquiring property would make them more willing to save - and habits of thrift were inherently moralizing. If governments would follow Wakefield's plan, "the colonies... would no longer be new societies, strictly speaking. They would be so many extensions of an old society." 57

What was understated in this first iteration of systematic colonization was the fact that, for the colonies to replicate conditions in the imperial state, they needed a bourgeoisie and an intelligentsia, if not also a landed aristocracy. It was the absence of these social classes that allowed democracy to run free, and for Wakefield, unbridled democracy inevitably debased culture and civilization. Early on, Wakefield had 
provided the formula for civilizing the colonies: exclude the majority of immigrants from free access to land, constrain them to work for wages and thus promote capitalist accumulation. Tying people to the land would eliminate cultural transience; making them work for wages would create habits of industry; early marriage would make for a flourishing population that would continue to be available for wage labour; wage labour would make it possible for investors to realize profit. Then, capitalist "wealth will bestow leisure; and leisure will bestow knowledge. Wealth, leisure, and knowledge mean civilization. Schools and colleges will be established. The arts and sciences will flourish... Abstract truth will be sought... A nation will be born free under a clear sky and will be highly instructed." 58

\section{Conclusion: Colonization as Education}

The doctrine of systematic colonization claimed to be able to form civilized societies and moral social subjects. Schools and the universal education of youth were inadequate to these ends. The establishment of civilized moral character in colonies was a precondition for the success of any institutional organization of education. These preconditions were themselves formed by the structural conditions and the material necessities and liberties in which people were placed. Wakefield claimed his policy would create culture and morality at the same time as it encouraged the free exercise of sexual reproduction, within heterosexual marriages. Appropriate material conditions would eliminate the physical misery imposed upon women in particular through Malthusian doctrines of restraint, making them at once comfortable, moral, free, and beautiful.

These are evidently educational discourses, but part of their specificity is their insistence that without a particular kind of class structure and culture, universal schooling was dangerous to political order and morality. Civilization demanded that a bourgeoisie, and perhaps also an aristocracy, be placed to shape the morals and habits of the common people. Without the structural conditions for class domination, colonization would result in moral and cultural degradation and wild, unfettered democracy would tyrannize the "best elements" in society.

Systematic colonization imagined that social relations could be engineered through state policy. Moral character for women stemmed not from enforced celibacy, but from the free enjoyment of "animal liberty." Once the colonization system was set in motion, it would work automatically to produce liberty, morality, comfort, and capitalist civilization, including institutions of learning. A Letter from Sydney inverted the typical relationship between school and community proposed by educational reformers of the period. For Wakefield, it was not the organization of formal institutions of learning that would reproduce imperial culture in the colonies: quite the reverse. Such institutions were worse than useless unless they were preceded by the proper relations among land, labour, and social classes. 


\section{Notes}

My thanks to Elsbeth Heamon, Jennifer Henderson, two anonymous reviewers, and the editors of Historical Studies in Education/Revue d'histoire de l'éducation.

1 Peter Burroughs, "Introduction," in The Founders of Canterbury, ed. Edward Jerningham Wakefield (London: Dawsons of Pall Mall, 1973 [1868]), v.

2 Bernard Bailyn, Education in the Forming of American Society (New York: Norton, 1960); Henry Barnard, School Architecture (New York: Teachers College Press, Columbia, 1970 [1847]); John Foster, An Essay on the Evils of Popular Ignorance (London: J. Holdsworth, 1821); John George Hodgins, The School House: Its Architecture and Internal Arrangements (Toronto: Department of Public Instruction, 1857); Phillip McCann, "Samuel Wilderspin and the Early Infant Schools," British Journal of Educational Studies 14, no. 2 (1966): 188-204; David Stow, The Training System (Glasgow: Blackie, 1845); Robert Sullivan, Lectures and Letters on Popular Education (Dublin: William Curry \& Co., 1842); Samuel Wilderspin, The Infant System (London: Hodson, 1852); John Woods, Account of the High School of Edinburgh (Edinburgh: Wardlaw, 1829).

3 Elizabeth Elbourne, "The Sin of the Settler: The 1835-36 Select Committee on Aborigines and Debates over Virtue and Conquest in the Early Nineteenth-Century British White Settler Empire," Journal of Colonialism and Colonial History 4, no. 3 (2003), doi:10.1353/cch.2004.0003; Kirsten McKenzie, "Discourses of Scandal: Bourgeois Respectability and the End of Slavery and Transportation at the Cape and New South Wales, 1830-1850," Journal of Colonialism and Colonial History 4, no. 3 (2003), 10.1353/cch.2004.0011.

4 John Harrington, "Edward Gibbon Wakefield, the Liberal Political Subject and the Settler State," Journal of Political Ideologies 20, no. 3 (2015): 333-51.

5 George F. Bartle, "Benthamites and Lancasterians - The Relationship Between the Followers of Bentham and the British and Foreign School Society During the Early Years of Popular Education," Utilitas 3, no. 2 (1991): 275-88; Edward R. Kittrell, "Bentham and Wakefield," Economic Inquiry 4 (1965): 28-40; William Thomas, The Philosophic Radicals: Nine Studies in Theory and Practice, 1817-41 (Oxford: Oxford University Press, 1979); Graham Wallas, Life of Francis Place (London: Longmans, Greene \& Co., 1898); Richard K. Webb, Harriet Martineau. A Radical Victorian (New York: Columbia University Press, 1960). The Radical faction in England was unable to unite around the question of colonization, a matter with consequences for policy in Canada in the 1830s. Annie L. Cot, "Entre expertise et utopie : Jeremy Bentham et la question des colonies," Tocqueville Review/La revue Tocqueville 31 (2011): 67-88; Bernard Semmel, "The Philosophic Radicals and Colonialism," Journal of Economic History 21 (1961): 513-25; Michael J. Turner, "Radical Agitation and the Canada Question in British Politics, 1837-41," Historical Research 79 (2006): 90-114.

6 Frank J. A. Broeze, "Private Enterprise and the Peopling of Australasia, 1831-50," Economic History Review, New Series, 35, no. 2 (1982): 235-53; Diane Brand, "Grand Designs Down Under: Utopias and Urban Projects in Mid-nineteenth Century New Zealand," Journal of Urban Design 22, no. 3 (2017): 308-25; Kingsley M. de Silva, "The Third Earl Grey and the Maintenance of an Imperial Policy on the Sale of Crown Lands in Ceylon, c. 1832-1852: Some Influences of Edward Gibbon Wakefield's Doctrines in a Tropical Colony," Journal of Asian Studies 27, no. 1 (1967): 5-20; Harrington, "Wakefield"; Richard C. Mills, The Colonization of Australia (1829-1842): The Wakefield Experiment in Empire Building (London: Sidwich \& Jackson, 1915); Jeremy Mouat, "Situating Vancouver Island in the British World, 1846-49," BC Studies, no. 145 (2005): 5-30; Adele Perry, Colonial Relations: The Douglas-Connolly Family and the Nineteenth-Century Imperial World, Critical Perspectives on Empire (New York: 
Cambridge University Press, 2015); Adele Perry, "The State of Empire: Reproducing Colonialism in British Columbia, 1849-1871," Journal of Colonialism and Colonial History 2, no. 2 (2001), 10.1353/cch.2001.0028; Karen Saunders, ed., Indentured Labour in the British Empire, 1834-1920 (London: Routledge, 1984).

7 Karl Marx, Capital: A Critique of Political Economy, vol. I: Capitalist Production (London: Lawrence \& Wishart, 1970 [1887]), 675. For more than a century, Marxist scholars have puzzled over the fact that the first volume of Marx's Capital ends with a critical chapter on Wakefield's scheme of systematic colonization ("The Modern Theory of Colonization") and not with the chapter that precedes it ("The Historical Tendency of Capitalist Accumulation"), which seems to point to the inevitability of capitalism's demise. Recent work argues that Marx thought Wakefield's project showed that capitalism could continue to reproduce itself through colonial and state-sponsored projects, despite highly developed class struggles in advanced capitalist nations. See Jack Barbelet, "Primitive Accumulation and Chinese Mirrors," Journal of Classical Sociology (in press); Carlos R. Braun, "Capitals Last Chapter," History of Political Economy 19, no. 2 (1987): 299-310; Edward R. Kittrell, "Wakefield's Scheme of Systematic Colonization and Classical Economics," American Journal of Economics and Sociology 32, no. 1 (1973): 87-112; H. O. Pappe, "Wakefield and Marx," Economic History Review, New Series, 4, no. 1 (1951): 88-97; Gabriel Piterberg and Lorenzo Veracini, "Wakefield, Marx, and the World Turned Inside Out," Journal of Global History 10, no. 3 (2015): 457-78; Joel Wainwright, "Uneven Developments: From the Grundrisse to Capital," Antipode 40 (2008): 879-97.

8 "Moral economy" has had a new lease on life as an approach to economics since the early 1990s. Nineteenth-century authors made the connection between the political and the moral economy through the mutual dependence of character and conduct. The marginalist revolution divorced the two. See, for a recent analysis, William Dixon and David Wilson, "Thomas Chalmers: The Market, Moral Conduct, and Social Order," History of Political Economy 42, no. 4 (2010): 723-46.

9 Edward Gibbon Wakefield, A Letter From Sydney. The Principal Town of Australasia: \& Other Writings on Colonization (London and New York: Dent Dutton, 1929 [1829]). Because Wakefield was so thoroughly compromised politically and morally, the Letter listed "Robert Gouger," an associate in colonization projects, as the editor. Wakefield himself, however, authored the letters on the basis of various reports and accounts of the colony available to him in prison.

10 Jean-Guy Prévost, "Espace public, action collective et savoir social: Robert Gourlay et le Statistical Account of Upper Canada," Histoire sociale/Social History 35 (2002): 109-39.

11 John Galt, Bogle Corbet, or The Emigrants. 3 vols. (London: Henry Colburn and Richard Bentley, 1831), quotation from vol. 3, 136-37. For more discussion of Galt's work, see K. McNeil, “Time, Emigration and the Circum-Atlantic World: John Galt's Bogle Corbet," in John Galt: Observations and Conjectures on Literature, History and Society, ed. Regina Hewitt (Lanham, MD: Bucknell University Press, 2012), 299-321. My thanks to Jennifer Henderson for pointing to Galt's literary work.

12 Anatole Browde, "Settling the Canadian Colonies: A Comparison of Two NineteenthCentury Land Companies," Business History Review 76 (2002): 299-335; Edward Brynn, "Politics and Economic Theory: Robert Wilmot Horton, 1820-1841," The Historian [1967?]: 260-77; Christopher Dunkin, "British American Politics," North American Review 39 (1839): 373-431; Paul Knaplund, James Stephen and the British Colonial System, 1813-1847 (Madison, WI: University of Wisconsin Press, 1953); James I. Little, "A. C. Buchanan and the Megantic Experiment: Promoting British Colonization in Lower Canada," Histoire sociale/Social History 46 (2013): 295-319; Mouat, "Situating Vancouver"; Perry, "State of Empire"; Prévost, "Espace public." 
13 For the kidnapping, see Philip Temple, A Sort of Conscience: The Wakefields (Auckland: Auckland University Press, 2002), 90-114. Wakefield parlayed his time in prison into a claim to have unique understanding of the various strata of what he called "the populace" and of the dangerous "rabble" that formed its lower strata. His alarmist pamphlet of 1831 argued that Parliament should arm "householders" for their selfprotection. Edward Gibbon Wakefield, Householders in Danger from the Populace (London: Effingham Wilson, 1831).

14 The lands report and Wakefield's other writing had nothing to say about the extinction of Indigenous title; the key issue was the extent to which land was still in possession of the Crown. See Arthur Doughtey, Report of the Public Archives of Canada for the Year 1924 (Ottawa: King's Printer, 1937); Charles Buller, "Appendix B: Public Lands and Emigration. Report to his Excellency the Governor-General," in Lord Durham's Report on the Affairs of British North America, ed. Sir Charles P. Lucas (Oxford: Clarendon Press, 1912 [1839]), 2: 213, n. 2; Adam Thom and William Kennedy, "Preliminary Report of the Assistant Commissioners of Municipal Inquiry. General Report of the Assistant Commissioners of Municipal Inquiry," in Lord Durham's Report, 3: 139. For Mill and municipal government, see Bruce Curtis, True Government by Choice Men? Inspection, Education and State Formation in Canada West (Toronto: University of Toronto Press, 1992).

15 Helen T. Manning, "E. G. Wakefield and the Beauharnois Canal," Canadian Historical Review 48, no. 1 (1967): 1-25. On the early history of the canal more generally, see Richard Viau, Du pain ou du sang. Les travailleurs irlandais et le canal Beauharnois (Montréal: Les Presses de l'Université de Montréal, 2013). On Ellice's attempts to monetize the seigneury, see André LaRose, "Objectif: commutation de tenure. Edward Ellice et le régime seigneurial (1820-1840)," Revue d'histoire de l'Amérique française 66, no. 3-4 (2013): 365-93.

16 R. Graham, "Juvenile Travellers: Priscilla Wakefield's Excursions in Empire, "Journal of Imperial and Commonwealth History 38, no. 3 (2010): 373-93; Bridget Hill, "Priscilla Wakefield as an Author of Children's Educational Books," Women's Writing 4, no. 1 (1997): 1-13; Vivien Jones, "Placing Jemima: Women Writers of the 1790s and the Eighteenth-century Prostitution Narrative,” Women's Writing 4, no. 2 (1997): 201-20.

17 Pretty much all of Priscilla Wakefield's work can be seen to focus on character formation, and it is in the field of what was later called ethology, as in the first American edition of her Sketches of Human Manners, Delineated in Stories Intended to Illustrate the Characters, Religion, and Singular Customs, of the Inhabitants of Different Parts of the World (Philadelphia: Johnson and Warner, 1811).

18 Priscilla Wakefield, Excursions in North America, Described in Letters from a Gentleman and his Young Companion to their Friends in England (London: Darnton and Harvey, 1806), 289. For an influential statement on natural religion, see Lant Carpenter, Principles of Education, Intellectual, Moral and Physical (London: Longman, Hurst, Rees, Orme, and Brown, 1820). Also see Camilla Leach, "Religion and Rationality: Quaker Women and Science Education, 1790-1850," History of Education Quarterly 35, no. 1 (2006): 69-90.

19 Temple, A Certain Conscience, 126, suggests that the Letter could have been written by Priscilla Wakefield, perhaps under a title such as The Traveler in Australia.

20 Harrington, "Liberal Subject," 344-45; Frances M. Trollope, Domestic Manners of the Americans, 2 vols. (London: Whittaker, Teacher \& Co, 1832).

21 Priscilla Wakefield, Excursions, 297. On Buller and masculinities, see Bruce Curtis, Ruling by Schooling Quebec: Conquest to Liberal Governmentality. A Historical Sociology (Toronto: University of Toronto Press, 2012), 390.

22 Priscilla Wakefield, Reflections on the Present Condition of the Female Sex, with Suggestions for its Improvement (New York: Garland, 1974 [1798]); Colin Jones, "Presidential 
Address: French Crossings IV: Vagaries of Passion and Power in Enlightenment Paris," Transactions of the Royal Historical Society, Series 6, no. 23 (2013): 3-36.

23 Temple, Sort of Conscience, 11-12.

24 Thomas R. Malthus, An Essay on the Principle of Population (Oxford: Oxford University Press, 2004 [1798]).

25 Wakefield, Reflections, 149, 180-89.

26 Wakefield, Reflections, 44.

27 Edward Wakefield, An Account of Ireland, Statistical and Political, 2 vols. (London: Longman, Hurst, Rees, Orme, and Brown, 1812); Temple, Sort of Conscience, 24-31, 42.

28 Great Britain, House of Commons, First Report of the Minutes of Evidence Taken Before the Select Committee of the House of Commons Appointed to Inquire Into the Education of the Lower Orders of the Metropolis (London: Gale and Fenner, 1816). Notice that while Wakefield's name appears in the index to the committee's final report, his testimony appears only in this source.

29 Wakefield, Ireland. Edward Gibbon Wakefield, England and America Compared (New York: Harper and Brothers, 1833), 101-4. On the controversy, see Bruce Curtis, "Priority, politics and pedagogical science. Part I: the mental steam-engine." Paedagogica Historica 52, no. 6 (2016): 661-73 and Bruce Curtis, "Priority, politics and pedagogical science. Part II: the priority dispute and a standard model of pedagogy." Paedagogica Historica 52, no. 6 (2016): 674-88.

30 Oz Frankel, "Scenes of Commission: Royal Commissions of Inquiry and the Culture of Social Investigation in Early Victorian Britain," European Legacy 4, no. 6 (1990): 20-49.

31 Wakefield, England and America; Edward Gibbon Wakefield, ed., A View of the Art of Colonization, With Present Reference to the British Empire; in Letters Between a Statesman and a Colonist (New York: Augustus M. Kelley, 1969 [1849]).

32 Knaplund, James Stephen, 69.

33 See note 4 supra.

34 R. N. Gosh, "Malthus on Emigration and Colonization: Letters to Wilmot-Horton," Economica ( February1963): 45-62. Wakefield would endlessly criticize WilmotHorton's emigration plan in the most disobliging terms. The main difference was that the latter sought to promote the emigration of peasants in household and perhaps in village units, inspired in part by Robert Owen's co-operative movement, while Wakefield was after capitalist farming. Wakefield, A Letter, Appendix, 100-06.

35 Wakefield, A Letter, 100-06. The change of heart may have been simple opportunism on Wakefield's part, but he had been influenced by Trollope's Domestic Manners after writing the Letter and before coming to Canada. Trollope argued, 2: 122-23, that "It is generally acknowledged that the suffering among our labouring classes arises from the excess of our population; and it is impossible to see such a country as Canada, its extent, its fertility, its fine climate, and know that it is British ground, without feeling equal sorrow and astonishment that it is not made the means of relief. How earnestly it is to be wished that some part of that excellent feeling which is for ever at work in England to help the distressed, could be directed systematically to the object of emigration to the Canadas. Large sums are annually raised for charitable purposes, by weekly subscriptions of one penny; were only a part of the money so obtained to be devoted to this object, hundreds of families might yearly be sent to people our own land."

36 Wakefield, A Letter, 68-77; "United States' Americans" as opposed, presumably, to Spanish or French or Russian Americans.

37 Wakefield, A Letter, 68-77.

38 Wakefield, A Letter, 68-77.

39 Wakefield, A Letter, 22-23, 27. 
40 Wakefield, A Letter, 47; italics added. On Durham's analysis, see Curtis, Ruling by Schooling, 437.

41 Wakefield, A Letter, 51.

42 Quoted in Harrington, Wakefield, 340-41.

43 Wakefield, A Letter, 175.

44 See Melanie White, "The Liberal Character of Ethological Governance," Economy and Society 34, no. 3 (2005): 474-94.

45 Charles de Secondat, baron de Montesquieu, The Spirit of the Laws, trans. Thomas Nugent (New York: Hafner, 1949).

46 David Hume, "Of National Characters," in The Complete Works and Correspondence of David Hume. Essays Moral, Political, and Literary (Charlottesville, VA: InteLex Corporation, 1995), Para. 2/35 mp 198 gp. 244. The discourse easily fed into stereotypical, chauvinist, or racist descriptions of different peoples and groups.

47 Wakefield, A Letter, 52-53.

48 Wakefield, A Letter, 61.

49 Wakefield, A Letter, 64.

50 Bruce Curtis, "Pastoral Power, Sovereignty and Class: Church, Tithe and Simony in Quebec," Critical Research in Religion 5, no. 2 (2017): 151-69.

51 The classic account of these events is found in Michael Polanyi, The Great Transformation: The Political and Economic Origins of Our Time (Boston: Beacon Press, 2001 [1944]).

52 See Mitchell Dean, The Constitution of Poverty. Toward a Genealogy of Liberal Governance (London: Routledge, 1991).

53 Alexis de Tocqueville, Voyages en Angleterre, Irlande, Suisse et Algérie. Oeuvres Complètes (Paris: Gallimard, 1958), 5: 32-33; my translation. See also B. Curtis, "Tocqueville and Lower Canadian Educational Networks," Encounters in Education 7 (2006): 113-29.

54 See Ursula R. Q. Henriques, "Bastardy and the New Poor Law," History Workshop Journal, no. 37 (1967): 103-29. Henriques shows that the clauses were modified in Parliament before the act was passed, but were intensely attacked in the following period. Also see Barbara Taylor, Eve and the New Jerusalem: Socialism and Feminism in the Nineteenth Century (New York: Pantheon, 1983), 200-01n.

55 For instance, Mitchell Dean, "The Malthus Effect: Population and the Liberal Government of Life," Economy and Society 44, no. 1 (2015): 18-39; Thomas Lemke, "From State Biology to the Government of Life: Historical Dimensions and Contemporary Perspectives of 'Biopolitics," Journal of Classical Sociology 10, no. 4 (2010): 421-38; Tanya M. Li, "To Make Live or Let Die? Rural Dispossession and the Protection of Surplus Populations," Antipode 41, no. S1 (2010): 66-93; Ulrich Tellmann, "Catastrophic Populations and the Fear of the Future: Malthus and the Genealogy of Liberal Economy," Theory, Culture and Society 30, no. 2 (2013): 135-55; Henrik Urdal, "People vs. Malthus: Population Pressure, Environmental Degradation, and Armed Conflict Revisited," Journal of Peace Research 42, no. 4 (2005): 417-34; Kasper Villadsen and Ayo Wahlberg, "The Government of Life: Managing Populations, Health and Scarcity," Economy and Society 44, no. 1 (2015): 1-17.

56 Wakefield, A Letter, 77.

57 Wakefield, $A$ Letter, 84.

58 Wakefield, A Letter, 47. 